\title{
Estudo do efeito de supressão no potencial evocado auditivo de tronco encefálico $* * * * *$
}

\author{
Study of suppression effect in the brainstem auditory evoked \\ potential
}

\author{
Carla Gentile Matas* \\ Fernanda Nivoloni O Silva** \\ Renata Aparecida Leite*** \\ Alessandra Giannella Samelli****
}

*Fonoaudióloga. Doutora em Ciências dos Distúrbios da Comunicação Humana pela Universidade Federal de São Paulo (Unifesp). Professora Assistente Doutora do Curso de Fonoaudiologia da Universidade de São Paulo (USP). Endereço para correspondência: R. Cipotânea, 51 São Paulo - SP - CEP 05360-000 (cgmatas@usp.br).

**Fonoaudióloga Clínica. Especialização em Fonoaudiologia pelo Departamento de Fisioterapia, Fonoaudiologia e Terapia Ocupacional da Faculdade de Medicina (FM) da USP.

***Fonoaudióloga Clínica. Doutoranda em Ciências pelo Programa de Pós-Graduação em Ciências da Reabilitação do Departamento de Fisioterapia, Fonoaudiologia e Terapia Ocupacional da FMUSP.

****Fonoaudióloga. Doutora em Ciências pelo Programa de PósGraduação em Fisiopatologia Experimental da FMUSP. Professora Assistente Doutora do Curso de Fonoaudiologia da USP.

*****Trabalho Realizado no Laboratório de Investigação Fonoaudiológico em Potenciais Evocados Auditivos do Curso de Fonoaudiologia da FMUSP.

Artigo Original de Pesquisa

Artigo Submetido a Avaliação por Pares

Conflito de Interesse: não

\begin{abstract}
Background: the suppression effect with contralateral white noise observed in the brainstem auditory evoked potential can be influenced by the efferent auditory system. Aim: to evaluate the suppression effect with contralateral white noise in the Brainstem Auditory Evoked Potential of individuals with normal hearing. Methods: 25 individuals, ranging in age from 18 to 30 years, of both genders, were submitted to a clinical history questionnaire, inspection of the external auditory canal, conventional audiometry, speech audiometry and acoustic immittance measurements. Only individuals with normal hearing thresholds were selected. The selected individuals underwent brainstem auditory evoked potential testing with and without contralateral white noise. Results: a significant statistical difference was observed between the situations with and without contralateral white noise, for wave I amplitude and waves III and V latencies. No statistical differences were observed for the interpeak latencies. Conclusions: the present study indicated increased latencies and reduced amplitudes of waves I, III and V with contralateral noise, when comparing the situations with and without noise. These results suggest a possible influence of the efferent auditory system on the response modulation of Brainstem auditory evoked potential when contralateral white noise is used.
\end{abstract}

Key Words: Auditory Evoked Potentials; Hearing; Evoked Potentials, Auditory, Brain Stem; Electrophysiology.

\section{Resumo}

Tema: o efeito de supressão com ruído branco contralateral verificado sobre o potencial evocado auditivo de tronco encefálico pode ter influência do sistema auditivo eferente. Objetivo: avaliar o efeito de supressão com ruído branco contralateral no potencial evocado auditivo de tronco encefálico em indivíduos com limiares auditivos dentro da normalidade. Método: participaram desta pesquisa 25 indivíduos, de 18 a 30 anos de idade, de ambos os sexos, que foram submetidos à anamnese, inspeção do meato acústico externo, audiometria tonal liminar, logoaudiometria e medidas de imitância acústica, com o objetivo de selecionar os indivíduos com acuidade auditiva normal. Em seguida os indivíduos selecionados realizaram o potencial evocado auditivo de tronco encefálico sem e com ruído branco contralateral. Resultados: na comparação entre as condições sem e com ruído branco contralateral verificou-se diferença estatisticamente significante para a amplitude da onda I e para as latências absolutas das ondas III e V, porém não foi observada diferença estatisticamente significante com relação às latências interpicos. Conclusões: o presente estudo verificou aumento nas latências e diminuição nas amplitudes das ondas I, III e V na presença de ruído contralateral, quando comparadas as condições com e sem ruído. Estes resultados sugerem uma possível influência do sistema nervoso auditivo eferente na modulação das respostas do potencial evocado auditivo de tronco encefálico quando se utiliza ruído branco contralateral.

Palavras-Chave: Potenciais Evocados Auditivos, Audição, Potenciais Evocados Auditivos do Tronco Encefálico; Eletrofisiologia. 


\section{Introduction}

The auditory evoked potential (AEP) is an objective method to assess the neuroelectrical activity of the auditory pathway - from the auditory nerve to the cerebral cortex - in response to an acoustic stimulus or event $(1,2,3)$.

The AEP can be classified according to the latency period of responses - the time elapsed from the presentation of the stimulus up to the appearance of response (4). Thus, the AEP are classified as short, middle and long latency (2.3).

Among the short-latency AEP, there is the brainstem auditory evoked potential (BAEP). The BAEP is generated by synchronous firing of neurons in structures along the ascending auditory pathway including the auditory nerve, cochlear nuclei, superior olivary nucleus, lateral lemniscus and inferior colliculus $(5,6,7,8)$.

The auditory system consists of ascending and descending auditory pathways that interact to each other in the processing of auditory information. The physiology of the ascending auditory pathway is well known and has been widely studied. However, the contribution of the corticofugal system (efferent) to the auditory processing has received little attention in the literature (9.10).

Recent studies have shown that the introduction of noise during the recording of evoked potentials can negatively affect the amplitude and / or the latencies of short, middle and / or long latency potentials $(11,12,13)$. Investigating this matter, some authors (14) suggested that this effect of noise on the auditory evoked potentials could be mediated by the efferent auditory system.

Therefore, the purpose of this study was to analyze the effect of suppression with contralateral white noise on the brainstem auditory evoked potential in normal hearing individuals.

\section{Methods}

This study was designed and developed at the Laboratory of Auditory Evoked Potentials Investigation of the Speech Language and Hearing Sciences Program, Faculty of Medicine, University of Sao Paulo. The research was approved by the Ethics in Research InCor, Hospital das Clinicas, under number 512/07.

Participants were 25 individuals from 18 to 30 years of age (mean age of 25.3 years old) of both genders. The individuals signed a consent form, in which the procedures to be performed were described, agreeing to their participation in the study.
The inclusion criteria for the sample composition were: no hearing impairment, no middle ear complaints, as well as hearing thresholds within normal limits.

First, in order to select individuals with normal hearing (i.e. hearing thresholds below $20 \mathrm{~dB}$ HL from $250 \mathrm{~Hz}$ to $8 \mathrm{kHz}$ ), participants were submitted to anamnesis, inspection of the external auditory canal, pure tone audiometry, speech audiometry and acoustic immittance measures.

Next, electrophysiological hearing assessment through BAEP was carried out in an electrically protected and acoustically isolated environment.

After cleaning the skin with abrasive paste, the electrodes were attached to the participants on vertex (Cz), forehead(Fpz), and right(M2) and left(M1)mastoid using electrolytic paste and adhesive tape. The impedance values of the electrodes were then verified. The impedance of the electrodes was found to be below $5 \mathrm{kOhms}$ for every participant.

The acoustic stimulus used was the click of rarefaction polarity, presented monaurally through a pair of TDH 39 earphones at $70 \mathrm{dBHL}$. The presentation rate was of 19 clicks per second, duration of 0.1 milliseconds, totalizing 2000 stimuli.

The BAEP was performed twice, with and without contralateral white noise. The BAEP with inclusion of white noise was performed at the intensity of $60 \mathrm{~dB}$.

The absolute latencies and amplitudes of waves I, III, V and the interpeaks I-III, III-V and -IV of BAEP, were analyzed in both conditions - with and without white noise. The results obtained in the BAEP with presence and absence of contralateral white noise were compared.

The paired t-student test was used for statistical analysis. The level of significance adopted was of 0.05 (5\%).

\section{Results}

Initially, a comparison between the right and left ears in the condition without contralateral white noise was carried out. No statistically significant differences in absolute latencies of waves I (p-value $=0.373)$, III ( $p$-value $=0.830)$ and V $(\mathrm{p}$-value $=0.382)$; interpeaks I-III (p-value $=0.523)$, III-V (p-value = $0.524)$ and $\mathrm{I}-\mathrm{V}$ (p-value $=0.841)$ as well for the amplitude values of waves I ( $\mathrm{p}$-value $=0.922)$, III $(p$-value $=0.223)$ and $\mathrm{V}(\mathrm{p}$-value $=0.479)$ were observed.

Regarding the condition with contralateral white noise, there were also no statistically significant differences when comparing the right and left ears for the absolute latencies of waves I 
$(\mathrm{p}$-value $=0.826)$, III $(\mathrm{p}$-value $=0.096)$ and V $(\mathrm{p}-$ value $=0.933)$; interpeaks I-III $(p$-value $=0.514)$, III$\mathrm{V}(\mathrm{p}$-value $=0.171)$ and $\mathrm{I}-\mathrm{V}(\mathrm{p}$-value $=0.909)$, and for the amplitude values of waves I ( $p$-value $=0.366$ ), III (p-value $=0.338)$ and V (p-value $=0.842)$.

Since no differences between the right and left ears in both BAEP conditions were observed, the values of latencies, interpeaks and amplitudes of both ears were considered for the following analysis.

When comparing the conditions with and without contralateral white noise, no statistically significant difference in the absolute latencies values of waves III and V were observed. In addition, a trend towards statistical significance for the latency of wave I (Table 1) was observed. In the comparison of interpeak latencies between the two conditions - with and without contralateral noise - no statistically significant difference was observed for any of the studied variables (Table 1 ).

Regarding the amplitude values, the difference was statistically significant only for wave I when comparing the two conditions of contralateral white noise (Table 2).

Figure 1 illustrates the pattern presented by the majority of tested ears with regard to latencies and amplitudes of waves I, III and V in the conditions with and without noise. In general, latency values of waves I, III and V were higher in the condition with noise when compared to the condition without noise, while the amplitude values were higher for the condition without noise when compared to the condition with noise. It may also be noted that the amplitudes presented greater dispersion variability when compared to the latencies for the three waves recorded.

TABLE 1. Mean, median, standard deviation and p-value of absolute latencies of waves I, III and V and interpeak latencies I-III,

III-V and I-V with and without contralateral white noise.

\begin{tabular}{|c|c|c|c|c|c|c|c|c|c|c|c|c|}
\hline \multirow{2}{*}{ Latencies } & \multicolumn{2}{|c|}{ Wave I } & \multicolumn{2}{|c|}{ Wave III } & \multicolumn{2}{|c|}{ Wave V } & \multicolumn{2}{|c|}{ I-III } & \multicolumn{2}{|c|}{ III-V } & \multicolumn{2}{|c|}{$\mathrm{I}-\mathrm{V}$} \\
\hline & Without & With & Without & With & Without & With & Without & With & Without & With & Without & With \\
\hline Mean & 1,61 & 1,64 & 3,74 & 3,79 & 2,13 & 2,16 & 1,86 & 1,86 & 3,98 & 4,02 & 5,60 & 5,65 \\
\hline Median & 1,60 & 1,64 & 3,72 & 3,76 & 2,12 & 2,16 & 1,84 & 1,84 & 3,98 & 4,00 & 5,56 & 5,64 \\
\hline \multicolumn{13}{|l|}{ Standard } \\
\hline \multicolumn{13}{|l|}{ Deviation } \\
\hline Minimum & 1,16 & 1,24 & 3,32 & 3,32 & 1,72 & 1,64 & 1,56 & 1,32 & 3,52 & 3,64 & 5,24 & 5,32 \\
\hline Maximum & 2,00 & 2,00 & 4,08 & 4,68 & 2,92 & 3,28 & 2,24 & 2,52 & 4,60 & 4,60 & 5,96 & 6,08 \\
\hline ample size & 50 & 50 & 50 & 50 & 50 & 50 & 50 & 50 & 50 & 50 & 50 & 50 \\
\hline p-value & 0,0 & & 0,00 & & 0,00 & & 0,17 & & 0,97 & & $\overline{0,1}$ & \\
\hline
\end{tabular}

Note: * - p-value statistically significant; \# p-value with a trend to significance. Paired t-Student test. 
TABLE 2. Mean, median, standard deviation and p-value of amplitude of waves I, III and V with and without contralateral

white noise.

\begin{tabular}{ccccccc}
\hline \multirow{2}{*}{ Amplitude } & \multicolumn{2}{c}{ Wave I } & \multicolumn{2}{c}{ Wave III } & \multicolumn{2}{c}{ Wave V } \\
& Without & With & Without & With & Without & With \\
& & & & & & \\
\hline Mean & 0,26 & 0,21 & 0,28 & 0,26 & 0,45 & 0,44 \\
\hline Median & 0,25 & 0,21 & 0,25 & 0,26 & 0,45 & 0,43 \\
\hline Standard Deviation & 0,13 & 0,10 & 0,12 & 0,11 & 0,15 & 0,15 \\
\hline Minimum & 0,00 & 0,00 & 0,06 & 0,01 & 0,12 & 0,12 \\
\hline Maximum & 0,66 & 0,43 & 0,57 & 0,55 & 0,86 & 0,88 \\
\hline Sample Size & 50 & 50 & 50 & 50 & 50 & 50 \\
\hline p-value & $0,010^{*}$ & & & & & \\
\hline
\end{tabular}

Note: * - p-value statistically significant; Paired t-Student test.

FIGURE 1. Dispersion graphs of latency values (A) and amplitude (B) of waves I, III and V in the conditions with and without noise.

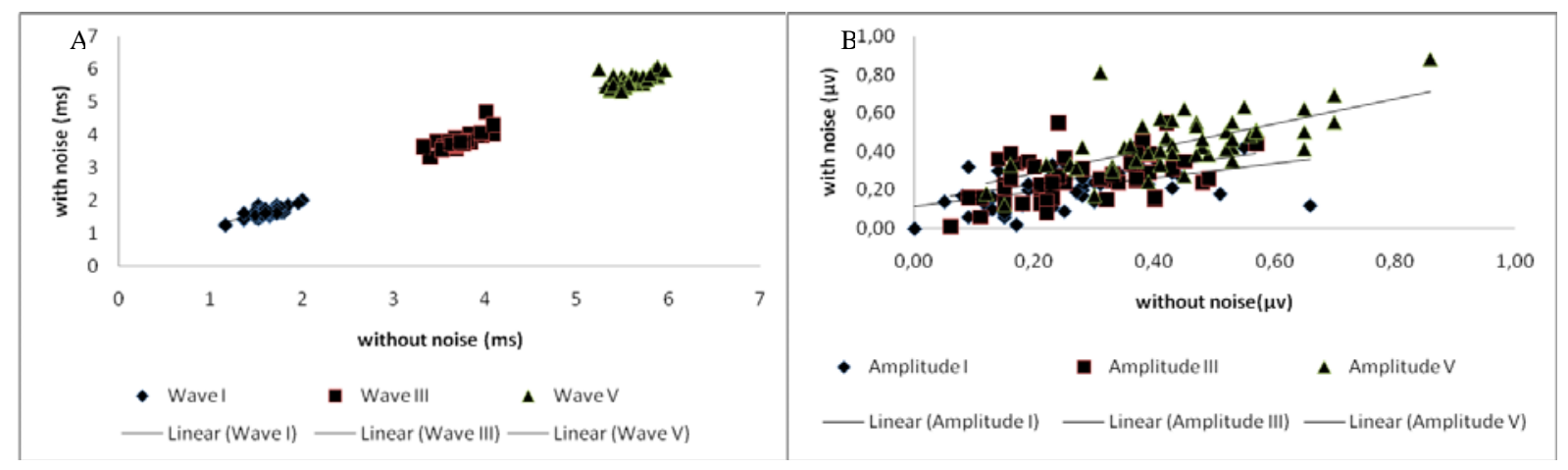

\section{Discussion}

Studies with animals show that the efferent auditory system begins in the auditory cortex, projecting to the medial geniculate body, inferior colliculus and auditory sub-collicular. Corticothalamic fibers project only to the medial geniculate body and to the ipsilateral thalamic reticular nucleus. However, corticocollicular fibers project bilaterally to the inferior colliculus. Corticofugal projections are bilateral to the subcollicular nuclei (9).
Corticofugal modulation has participation even in the cochlea via the olivocochlear neurons that start at the superior olivary complex. The central nucleus of the inferior colliculus is projected not only to the medial geniculate body, but also to medial olivocochlear neurons, which, in turn, are mainly projected to the ipsilateral and contralateral outer hair cells (9). Thus, the structures assessed by BAEP receive innervation of the efferent corticofugal system and could be influenced by the modulation of this system when necessary. 
The presence of broadband noise can cause a decrease in electrical activity of afferent neurons because it induces an adaptive masking in primary afferents, reducing the firing rates evoked by an additional stimulus (in this case the BAEP click) and increasing the latency of responses (10).

In addition, the broadband noise can reduce the phase synchronization of the primary afferent to an additional stimulus, reducing the amplitude of response to this stimulus. It can also activate the efferent neurons that would cause some suppression of afferent responses (10) as it was observed in this study - increased latencies (statistically significant for waves III and V, and a trend towards significance for the wave I) and decreased amplitude (statistically significant for wave I) were observed in the condition with contralateral white noise as compared to the condition without noise.

Such noise effect on the BAEP wave(s) has already been observed in previous studies however, with smaller magnitude. This difference can be explained by the different applied parameters. Some authors (15) used ipsilateral broadband noise and found that noise levels equal to or greater than 20 $\mathrm{dB}$ of effective masking caused an increase in latency and a decrease in amplitude of wave V, according to the increasing noise level.

In turn, another study (16) found significant prolongation of waves III and V with contralateral white noise at $90 \mathrm{~dB}$ HL and click at $70 \mathrm{~dB}$ HL. For noise intensity at $80 \mathrm{~dB} \mathrm{HL}$, a significant increase was observed only for wave V. Below this intensity no latency alteration was observed for any of the waves. Based on these findings, the authors concluded that the presence of contralateral white noise at intensity levels below $80 \mathrm{~dB}$ HL did not affect the responses of BAEP and suggested that the observed effect on the waves would be influenced by the central masking.

Increased latency and decreased amplitude of wave $\mathrm{V}$, for individuals with normal hearing and for individuals with hearing loss have been reported when effective ipsilateral broadband masking was applied (17). Similar results, also using continuous ipsilateral broadband noise, were obtained in another study, in which a slight change in wave I, but a significant change to the latency of wave $\mathrm{V}$ was observed (18).
In a study using contralateral noise, no significant change in wave $\mathrm{V}$ was observed. However, significant change was observed in the middle latency component of $\mathrm{Pb}$. The authors reported that, with the use of contralateral noise, unlike previous research that used ipsilateral noise, the observed effects could not be attributed only to ipsilateral cochlear events or brainstem. In contrary, the effects would be influenced by central mechanisms, although such physiological mechanisms are not yet known (12).

The results of the study mentioned above (12) are consistent with the findings of a prior investigation (19), in which the effect of ipsilateral and contralateral noise on wave $V$ of BAEP and on the Auditory Steady State Evoked Potentials (ASSEP) at $40 \mathrm{~Hz}$ was analyzed. The authors found no change in wave $\mathrm{V}$, but verified a decreased in the amplitude of ASSEP. They concluded that the observed effects were of central origin because the ASSEP are generated primarily in the auditory cortex (19).

The two previously mentioned studies $(12,19)$, although they have not yet been replicated with regard to wave $\mathrm{V}$ of BAEP, suggest a central origin for the effects of noise on the AEP. This indicates the need for further studies, which could clarify the influence of the efferent system in conditions with contralateral noise, resulting in a possible suppressive effect also for the middle and long latency potentials.

In the investigation of the masking effect on N1 and P2 waves (14), it was evidenced that the presence of broadband noise can significantly alter the amplitudes of the waves - with N1 amplitude attenuation and P2 amplitude increase being observed. The authors suggested that this effect could be mediated by the efferent system, as it occurs in cases where the activation of the olivocochlear auditory efferent system attenuates the otoacoustic emissions with the application of contralateral noise (14).

Investigating the Middle Latency Auditory Evoked Potential with click stimulus and contralateral music in normal hearing adults (20), a decrease in wave amplitudes of the ear contralateral to the music stimulus in all electrode positions and for all subjects was reported - although this difference was not statistically significant. Although having stated that further studies are needed, the authors agreed to the hypothesis stated by the previously mentioned study (14) that this effect could be influenced by the efferent system. 


\section{Conclusion}

In the present study, increase in latencies and decrease in amplitudes of waves I, III and V in the presence of contralateral noise was observed when compared to the condition without noise. These results may suggest the influence of the efferent auditory system in modulating BAEP responses when contralateral white noise is applied.

\section{References}

1. Junqueira CAO, Frizzo ACF. Potenciais evocados auditivos e curta, média e londa latência. In: Aquino AMCM, org. Processamento auditivo - Eletrofisiologia e Psicoacústica. São Paulo: Lovise; 2002. p.63-85.

2. Hall JW. Overview of auditory neurophysiology: past, present, and Future. In: Hall JW org. New handbook of auditory evoked responses. Boston: pearson education Inc; 2007. p.1-34

3. Ruth RA, Lambert PR. Auditory evoked potentials. Otolaryngol Clin North Am. 1991;24(2):349-70.

4. Simões MB, Souza RR, Schochat E. Efeito de supressão nas vias auditivas: um estudo com os potenciais de média e longa latência. Rev Cefac. 2009;11(1):150-7.

5. Möller AR, Janneta P, Bennett M, Möller MB. Intracranially recorded responses from human auditory nerve: new insights into the origin of brainstem evoked potentials. Electroencephalogr Clin Neurophysiol. 1981; 52:18-27.

6. Moller AR, Jannetta P. Neural generators of the auditory brainstem response. In: Jacobson, J. editors. The auditory brainstem response. San Diego: College-Hill Press; 1985. p.13-31.

7. Song JH, Banai K, Russo NM, Kraus N. On the relationship between speech-and nonspeech- evoked auditory brainstem responses. Audiol Neurootol. 2006;11:233-41.

8. Palmer AR. Anatomy and physiology of the auditory brainstem. In: Burkard RF, Don M, Eggermont JJ. editors. Auditory evoked potentials: basic principles and clinical application. Baltimore: Lippincott Williams \& Williams, 2007. p.200-28.

9. Suga N, Ma X. Multiparametric corticofugal modulation and plasticity in the auditory system. Nat Rev Neurosci. 2003; 4:783-94.

10. Tomchik SM, Lu Z. Modulation of Auditory Signal-toNoise Ratios by Efferent Stimulation. J Neurophysiol. 2006; 95:3562-70
11. Salisbury DF, Desantis MA, Shenton ME, McCarley RW. The effect of background noise on P300 to suprathreshold stimuli. Psychophysiology. 2002;39:111-5.

12. Özdamara O, Bohórquez J. Suppression of the Pb (P1) component of the auditory middle latency response with contralateral masking. Clin Neurophysiol. 2008;119:187080 .

13. Weihing J, Musiek FE. An Electrophysiological Measure of Binaural Hearing Noise. J Am Acad Audiol. 2008; 19(6):481-95.

14. Salo SK, Lang H, Salmivalli AJ, Johansson RK, Peltola MS. Contralateral white noise masking affects auditory N1 and P2 waves differently. J Psychophysiol. 2003; 17(4):189-94.

15. Burkard R, Hecox K. The effect of broadband noise on the human brainstem auditory evoked response. I. Rate and intensity effects. J Acoust Soc Am. 1983;74(4):120413.

16. Rosenhamer HJ, Holmkvist C. Latencies of ABR (waves III and V) to binaural clicks: effects of binaural time and intensity differences. Scand Audiol. 1983;12:201-7.

17. Hecox KE, Patterson J, Birman M. Effect of broadband noise on the human brain stem auditory evoked response. Ear Hear. 1989;10(6):346-53.

18. Burkard RF, Sims D. A comparison of the effects of broadband masking noise on the auditory brainstem response in young and older adults. Am J Audiol. 2002;11:13-22.

19. Galambos R, Makeig S. Physiological studies of central masking in man. I: The effects of noise on the $40-\mathrm{Hz}$ steady-state response. J Acoust Soc Am. 1992;92(5):268390.

20. Eisencraft T, Miranda MF, Schochat E. Comparação dos Potenciais de Latência Média com ou sem estímulo musical. Rev Bras Otorrinolaringol. 2006;72(4):465-9. 